\title{
The Effect of Fermented Sago Pulp on Performances and Income Over Feed Cost (IOFC) Local Sheep
}

\author{
Mustapa Zahri Ritonga, Hasnudi, Iskandar Sembiring, Tri Hesti \\ Wahyuni, Nevy Diana Hanafi
}

Animal Production Program, Faculty of Agriculture, University of North Sumatera, Medan 20155

Email: mustapa.zahri274@gmail.com

\begin{abstract}
This study aims to determine the effect of fermented sago pulp in rations on performance (weight gain, feed consumption, feed conversion) and local sheep's income over feed cost (IOFC). This research was carried out in the community farms of Karang Rejo Village, Stabat District, Langkat Regency. This research started from March to June 2017. The design used was complete randomized design (RAL), with 4 treatment of 5 replications. Each replication consisted of 1 local sheep with an initial weight of $11.05 \pm 0.56 \mathrm{~kg}$. The treatment consisted of P1 (50\% sago pulp without fermentation + forage), P2 (60\% of sago pitch without fermentation + forage), P3 (50\% fermented sago pulp + forage), and P4 (60\% fermented sago pulp + ). The observed variables were performance (body weight gain, feed consumption, feed conversion) and income over feed cost (IOFC).

The results showed that the treatment of fermented sago pulp gave a very real effect $(\mathrm{P}<0.01)$ on daily weight gain. The mean of P1 $=33,05 \mathrm{~g}, \mathrm{P} 2=39,95 \mathrm{~g}, \mathrm{P} 3=46,57 \mathrm{~g}, \mathrm{P} 4=54,38 \mathrm{~g}$. The consumption of fermented sago pulp treatment has a real effect $(\mathrm{P}<0,01)$. With average $\mathrm{P} 1=$ $486,38 \mathrm{~g}, \mathrm{P} 2=548,68 \mathrm{~g}, \mathrm{P} 3=604,69 \mathrm{~g}, \mathrm{P} 4=671,11 \mathrm{gr}$. Against the conversion of fermented sago pulp fermentation treatment gave a real effect $(\mathrm{P}<0.05)$. With average $\mathrm{P} 1=14.78, \mathrm{P} 2=$ 13.90, P3 $=12.99, \mathrm{P} 4=12,49$. IOFC the highest local sheep is Rp. 121.568 on treatment of $\mathrm{P} 4$ and IOFC lowest at treatment P1 equal to Rp.73.315. The conclusion of the research shows that the utilization of fermented sago pulp can increase body weight gain, feed consumption, local sheep feed conversion. P4 treatment economically has a better economic level than P1,P2 and P3.
\end{abstract}

I. Introduction

The Ruminants such as cattle, buffalo, sheep and goats are herbivorous livestock that have a different digestive system than non ruminants (such as poultry and pigs). The digestive system of ruminants could utilize high fiber feed. Therefore, ruminants could consume forage so much, such as natural vegetation, forage and agricultural by-products.

The Ruminants are able to digest forage including grasses which generally contain high cellulose. This is caused by the presence of microorganisms in the rumen, the higher the population, the higher the ability to digest cellulose used for population growth and development. Microorganisms in the rumen require protein, mineral energy and a number of vitamins [1]. 
The effect of nutrition on carcass composition involves the interaction between consumption and composition of feed. Increase or decrease in feed consumption can be related to the quality of feed and as a result, can affect the characteristics of meat produced [2].

Using sago pulp is an alternative to sheep feed. Sago pulp content is CP $3.84 \%$, EE $1.48 \%$, CF $14.51 \%, \mathrm{Ca} 0.32 \%$ and Metabolic Energy $1.352 \mathrm{kcal} / \mathrm{kg}$. Although it is known that its use as a ration has problems such as digestibility and low nutrient content and high levels of crude fiber and low levels of protein. By doing fermentation, the sago pulp content can be increased. Not only that, sago pulp fermentation can increase digestibility and eliminate alfatoxin or toxic compounds [3].

The process of fermentation of feed ingredients by microorganisms causes beneficial changes such as improving the quality of feed ingredients, even from the aspect of nutrition and digestibility and increasing storability of this. Fermentation products usually have higher nutritional value than the original ingredients [4].

The potential use of sago pulp as feed has a limiting factor that is low crude protein content and high crude fiber. In order to become animal feed ingredients that are rich in protein and vitamins, the sago pulp can be processed with fermentation technology [5].

\section{Materials and Methods}

This research has done on the farm of people of Karangrejo, Kecamatan Stabat, Kabupaten Langkat. This research started on March to June 2017.

The materials used were 20 local sheep, feed ingredients consisting of field grass, sago pulp, Aspergillus niger as fermented sago pulp fermenter, additional feed as reinforcing feed, medicines such as Permentyhl 5\% as a medicine for bloating, medication for worms (Kalbazen), terramycin (salepmata), vitamin B-complex is given to maintain the immune system of sheep, drinking water, disinfectant (Rodalon).

The tools used were 20 individual cages with $1 \times 1.5 \mathrm{~m}$ size, 20 units of feed and 20 drinking water containers, weighing scales to weigh $150 \mathrm{~kg}$ with a sensitivity of $50 \mathrm{~g}$, weighing $2 \mathrm{~kg}$ with a sensitivity of $10 \mathrm{~g}$ for weighing feed, lighting equipment, plastic burlap, stationery, brooms, shovels to clean cages, water buckets, raffia ropes, plastic drums as fermentation sites, thermometers to determine the condition of the temperature of the cage, sickles to scavenge the grass that will be given to the sheep.

The parameters of this research are consumption of the feed, body weight gain, feed conversion and Income Over Feed Cost (IOFC). 
Table 1. The composition of fermented sago pulp ration during the research

\begin{tabular}{lcccr}
\hline \multirow{2}{*}{ Feed Ingredients } & \multicolumn{4}{c}{ Treatment $(\%)$} \\
\cline { 2 - 5 } & P1 & P2 & P3 & \multicolumn{1}{c}{ P4 } \\
\hline Non fermented sago pulp & 50,00 & 60,00 & 0,00 & 0,00 \\
Fermented sago pulp & 0,00 & 0,00 & 50,00 & 60,00 \\
Palm kernel meal & 14,00 & 9,00 & 14,00 & 9,00 \\
Rice Bran & 23,00 & 18,00 & 23,00 & 18,00 \\
Soybean meal & 5,00 & 5,00 & 5,00 & 5,00 \\
Urea & 1,00 & 1,00 & 1,00 & 1,00 \\
Mineral & 2,00 & 2,00 & 2,00 & 2,00 \\
Molasses & 5,00 & 5,00 & 5,00 & 5,00 \\
\hline Total & 100 & 100 & 100 & 100 \\
\hline Nutrition Ration per Treatment: & & & & \\
CP $(\%)$ & 7,73 & 6,86 & 14,42 & 14,89 \\
CF $(\%)$ & 16,91 & 16,76 & 14,26 & 13,58 \\
EE $(\%)$ & 2,10 & 1,78 & 1,93 & 1,58 \\
\hline
\end{tabular}

\subsection{Consumption of the feed}

Feed consumption is obtained by calculating the amount of feed given with the remaining food every day and expressed by grams per head per day in dry matter.

Feed consumption $=$ Feed given $($ gram $)-$ Remnant feed $($ gram $)$

2.2 Body weight gain

Body weight gain is calculated by dividing the difference in body weight (final weight - initial weight) by the length of the weighing day. Performed every 14 days during the study, expressed by grams per head per day. Body weight gain is calculated by dividing the difference in body weight (final weight - initial weight) by the length of the weighing day. Performed every 14 days during the research, expressed by grams per head per day.

2.3 Feed conversion

$$
\text { Body weight gain }=\frac{\text { Initial weight }- \text { first weight }}{\text { Maintenance time }}
$$

Feed conversion is a comparison between the amount of feed consumption and body weight gain during maintenance.

$$
\text { Feed Conversion }=\frac{\text { Consumption of the feed }}{\text { Body Weight Gain }}
$$

\subsection{Income Over Feed Cost}

IOFC is based on the selling price of sheep and the cost of feed issued during the research.

IOFC = (final weight of sheep - initial weight of sheep $\mathrm{x}$ selling price of sheep $/ \mathrm{kg}$ ) - (total feed consumption $\mathrm{x}$ price of feed $/ \mathrm{kg}$ )

Data Analysis

The research method used was a completely randomized design (CRD) consisting of 4 treatments and 5 replications in which each replication consisted of 1 local sheep.

The linear model used for completely random design (CRD) is:

$$
Y i j=\mu+\alpha i+i j+\Sigma i j
$$


Description:

Yij = the value of observations from the results of the-i to test treatment

$\mu \quad=$ population mean

$\alpha \mathrm{i}=$ influence of treatment on level $\mathrm{i}$

eij $=$ the effect of error from the $-\mathrm{j}$ test treatment

3. Result and Discussion

3.1 Consumption of the Feed

The consumption of local sheep dry matter is calculated based on the dry matter contained in the feed. The collection of feed consumption data was taken every day during the research.

Table 2. Average consumption of local sheep dry matter during the study (g/ head / day)

\begin{tabular}{|c|c|c|c|c|c|c|c|}
\hline \multirow{2}{*}{ Treatment } & \multicolumn{5}{|c|}{ Repetition } & \multirow{2}{*}{ Total } & \multirow{2}{*}{ Average $\pm S D$} \\
\hline & 1 & 2 & 3 & 4 & 5 & & \\
\hline $\mathrm{P} 1$ & 487,88 & 557,90 & 488,17 & 496,24 & 527,40 & 2557,40 & $511,48 \pm 30,56^{\mathrm{B}}$ \\
\hline $\mathrm{P} 2$ & 562,31 & 570,12 & 515,07 & 511,19 & 535,31 & 2694,00 & $538,80 \pm 26,79^{\mathrm{AB}}$ \\
\hline P3 & 505,26 & 554,86 & 519,81 & 608,43 & 573,64 & 2762,00 & $552,40 \pm 8,53^{\mathrm{A}}$ \\
\hline $\mathrm{P} 4$ & 586,21 & 567,43 & 570,83 & 572,55 & 584,69 & 2881,71 & $576,34 \pm 41,47^{\mathrm{A}}$ \\
\hline
\end{tabular}

From Table 2 shows the highest average in P4 treatment (ration with $60 \%$ fermented + forage sago pulp) which is 576.34 grams / head / day and the lowest average in P1 treatment (ration with 50\% sago pulp without fermentation + forage) that is equal to $511.48 \mathrm{grams} / \mathrm{head} / \mathrm{day}$.

The ability of sheep to consume dry matter is $2.5 \%$ of body weight. During the study $10 \%$ of the body weight was given or about $1100 \mathrm{~g} /$ head / day. Whereas in the implementation of sheep consume feed below the rate of ability to consume feed in dry ingredients. This is due to the texture of a smooth feed that causes the feed to be unreachable to the sheep perfectly. This causes a residual feed every day.

Table 3. Analysis of the diversity of dry matter consumption during the research

\begin{tabular}{|c|c|c|c|c|c|c|}
\hline \multirow{2}{*}{ SOD } & \multirow{2}{*}{ DOF } & \multirow{2}{*}{ TQ } & \multirow{2}{*}{ MS } & \multirow{2}{*}{ F COUNT } & \multicolumn{2}{|c|}{ F Table } \\
\hline & & & & & 0,05 & 0,01 \\
\hline Treatment & 3 & 10994,36 & 3664,78 & $4,26^{*}$ & 3,49 & 5,95 \\
\hline Error & 16 & 13778,18 & 861,13 & & & \\
\hline Total & 19 & 24772,54 & & & & \\
\hline
\end{tabular}

Description: *significant different effect $(\mathrm{P}<0,05)$

Based on the analysis of the diversity of dry matter consumption during the study had a significant effect $(\mathrm{P}<0.05)$. The existence of significant differences in the consumption of dry matter is influenced by several factors, one of the factors that influence feed consumption is palatability. This shows that the administration of fermented sago pulp affects the palatability of sheep.

Based on the Duncan test results showed that the P1 treatment was significantly diffe rent from the treatment of P2, P3 and P4. However P2 is not significantly different from P3 and P4.

\subsection{Body Weight Gain}

Local sheep daily body weight gain is calculated by dividing the final body weight difference with the initial body weight divided by the length of the weighing day. Data retrieval of body weight is taken every two weeks during the research.

Table 3. Average daily weight gain of local sheep during the research (g/ head / day)

\begin{tabular}{ccccccrcr}
\hline \multirow{2}{*}{ Treatment } & \multicolumn{5}{c}{ Repetition } & \multirow{2}{*}{ Total } & \multirow{2}{*}{ Average \pm SD } \\
\cline { 2 - 6 } & 1 & 2 & 3 & 4 & 5 & & \\
\hline P1 & 35,95 & 37,38 & 34,05 & 42,62 & 39,76 & 189,76 & $37,95 \pm 3,34^{\mathrm{A}}$ \\
P2 & 38,33 & 44,52 & 39,52 & 42,38 & 44,52 & 209,29 & $41,86 \pm 2,84^{\mathrm{A}}$ \\
\hline
\end{tabular}




\begin{tabular}{llllllll}
\hline P3 & 41,19 & 48,33 & 42,38 & 49,76 & 47,86 & 235,71 & $47,14 \pm 3,40^{\mathrm{B}}$ \\
P4 & 50,71 & 45,00 & 53,57 & 47,62 & 52,14 & 249,05 & $49,81 \pm 3,48^{\mathrm{B}}$ \\
\hline
\end{tabular}

From Table 3 shows the highest average in P4 treatment (ration with $60 \%$ fermented + forage sago pulp) which is 49.81 grams / head / day and the lowest average in P1 treatment (ration with 50\% sago pulp without fermentation + forage) that is equal to $37.95 \mathrm{grams} /$ head / day

Table 4. Daily analysis of body weight gain during the research

\begin{tabular}{|c|c|c|c|c|c|c|}
\hline \multirow{2}{*}{ SOD } & \multirow{2}{*}{ DOF } & \multirow{2}{*}{ TQ } & \multirow{2}{*}{ MS } & \multirow{2}{*}{ F count } & \multicolumn{2}{|c|}{ F Table } \\
\hline & & & & & 0,05 & 0,01 \\
\hline Treatment & 3 & 423,24 & 141,08 & $13,16 * *$ & 3,49 & 5,95 \\
\hline Error & 16 & 171,59 & 10,72 & & & \\
\hline Total & 19 & 594,83 & & & & \\
\hline
\end{tabular}

Keterangan: **Very significant different effect

From Table 4 it can be seen that the analysis of daily body weight gain diversity during the study gave a very significant different effect $(\mathrm{P}<0.01)$. The existence of very significant differences in daily body weight gain is associated with the consumption of dry matter.

Duncan's test results show that P1 and P2 are not significantly different from each other and P3 and $\mathrm{P} 4$ are also not significantly different.

\subsection{Feed Conversion}

Local sheep feed conversion is calculated by dividing the average rate of consumption of dry matter per head per day with the average production of body weight per head per day.

Table 5. Average local sheep feed conversion

\begin{tabular}{|c|c|c|c|c|c|c|c|}
\hline \multirow{2}{*}{ Treatment } & \multicolumn{5}{|c|}{ Repetition } & \multirow{2}{*}{ Total } & \multirow{2}{*}{ Average $\pm S D$} \\
\hline & 1 & 2 & 3 & 4 & 5 & & \\
\hline $\mathrm{P} 1$ & 13,57 & 14,92 & 14,34 & 11,64 & 13,26 & 67,74 & $13,55 \pm 1,25^{\mathrm{A}}$ \\
\hline $\mathrm{P} 2$ & 14,67 & 12,08 & 13,03 & 12,06 & 12,02 & 64,59 & $12,92 \pm 1,08^{\mathrm{A}}$ \\
\hline P3 & 14,23 & 11,74 & 11,75 & 11,51 & 12,22 & 61,45 & $12,29 \pm 1,1^{\mathrm{AB}}$ \\
\hline $\mathrm{P} 4$ & 9,96 & 12,33 & 9,70 & 12,78 & 11,00 & 55,77 & $11,15 \pm 1,38^{\mathrm{B}}$ \\
\hline
\end{tabular}

From Table 5 shows the highest average in P1 treatment (ration with $60 \%$ sago pulp without fermentation + forage) that is equal to 13.55 and the lowest average in P4 treatment (ration with $60 \%$ fermented + forage sago pulp) is 11,15 .

Table 6. Feed conversion diversity analysis during the research

\begin{tabular}{ccccccc}
\hline \multirow{2}{*}{ SOD } & DOF & TQ & MS & F count & \multicolumn{2}{c}{ F table } \\
\cline { 3 - 6 } & & & & & 3,05 & 0,01 \\
\hline Treatment & 3 & 15,61 & 1,46 & & 3,49 & \\
\hline Error & 16 & 23,40 & & & \\
\hline Total & 19 & 39,02 & & & \\
\hline
\end{tabular}

Keterangan: *significant different effect $(\mathrm{P}<0,05)$ 
From Table 6 it can be seen that the analysis of the diversity of feed conversion during the study had a very significant effect $(\mathrm{P}<0.05)$. Feed conversion figures show results that are not much different but affect the economic value and efficiency in the use of feed.

Based on the Duncan test results showed that P4 was significantly different compared to treatmen $\mathrm{P} 1$, P2 and P3. Where the lowest conversion value is in the P4 treatment. While the treatment of P1, P2 and $\mathrm{P} 3$ is not significantly different.

\subsection{Income Over Feed Cost (IOFC)}

One way to calculate income simply is the calculation of Income Over Feed Cost (IOFC). Income analysis in this way is based on the selling price of the sheep and the cost of feed issued during the research.

Table 7. Average of Income Over Feed Cost (IOFC) of local sheep (Rp)

\begin{tabular}{cccccc}
\hline Treatment & BWG & $\begin{array}{c}\text { Price of Livestock } \\
(\mathrm{Rp})\end{array}$ & $\begin{array}{c}\text { Consumption } \\
(\mathrm{Kg})\end{array}$ & $\begin{array}{c}\text { Cost of Feed } \\
(\mathrm{Rp})\end{array}$ & IOFC (Rp) \\
\hline P1 & 1,39 & 76.340 & 2,08 & 3.024 & 73.315 \\
P2 & 1,68 & 92.290 & 2,29 & 3.363 & 88.926 \\
P3 & 1,96 & 107.580 & 2,47 & 3.670 & 103.909 \\
P4 & 2,28 & 125.620 & 2,69 & 4.051 & 121.568 \\
\hline
\end{tabular}

From Table 7. shows that the highest IOFC value was found in P4 treatment of Rp. 121,568. Thus the P4 treatment economically has a better economic level than the P1, P2 and P3 treatments.

4. Conclusion

The use of sago pulp fermented to $60 \%$ level in the ration can increase body weight gain, feed consumption, reduce the value of feed conversion in local sheep. IOFC shows that the fermented sago pulp has a good economic level with a low price with high feed quality.

\section{References :}

[1] Siregar. S. B. 1994. Ransum Ternak Ruminansia. Penebar Swadaya. Jakarta.

[2] Soeparno. 1994. Ilmu dan Teknologi Daging: Gadjah Mada University Press. Yogyakarta

[3] Antawidjaja, T., I.A.K. Bintang. Supriati. A.P Sinurat Dan I.P. Kompiang. 1997. Penggunaan Ampas Kirai (Metroxylon Sago) Dan Hasil Fermentasinya Sebagai Bahan Pakan Itik Yang Sedang Tumbuh. Jitv 2(3): $175-180$.

[4] Winarno, F. G. dan S. Fardiaz. 2005. Pengantar Teknologi Pangan. Gramedia. Jakarta.

[5] Rumalatu. 1981. Potensi dan Pemanfaatan Sagu. Kanisius. Yogyakarta. 